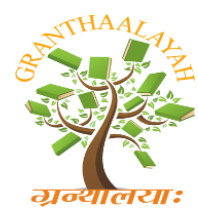

INTERNATIONAL JOURNAL OF RESEARCH GRANTHAALAYAH

A knowledge Repository

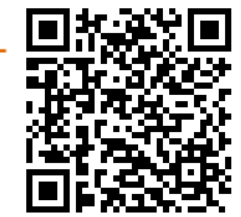

Science

\title{
EFFECT OF NITROGEN FERTILIZER ON GROWTH, YIELD AND YIELD COMPONENTS OF MAIZE (ZEA MAYS L.) IN DECHA DISTRICT, SOUTHWESTERN ETHIOPIA
}

\author{
Mitiku Woldesenbet ${ }^{* 1}$, Asnakech Haileyesus ${ }^{2}$ \\ ${ }^{* 1}$ Mizan-Tepi University, Department of Plant Sciences, P. O. Box 260, Mizan Teferi, \\ ETHIOPIA \\ ${ }^{2}$ Decha District Agriculture and Natural resource Office, P.o.Box 156, Awurada, ETHIOPIA
}

\begin{abstract}
Maize response to high nitrogenous fertilization levels is a means among other means to know maximum productivity, from this perspective, a field nitrogen management trial using five $N$ levels (0, 23, 46, 69 and $92 \mathrm{~kg} \mathrm{~N} / \mathrm{ha}$ ) with three replications. The study was conducted in 2015 in Decha District, Modyo Gombera Kebele of Kaffa Zone, SNNPR State. The experiment was laid out in RCBD. The result of this study indicated that effects of different rates of $N$ fertilizer had influenced the growth and yield components of maize. The tallest plant $(360.66 \mathrm{~cm})$ was recorded from the application of $92 \mathrm{~kg} \mathrm{~N} \mathrm{ha-1}$ and the shortest $(347.33 \mathrm{~cm})$ from no N application. The ANoVA for the number of kernels per ear showed that the lowest kernels per ear (497.86) were obtained from no $N$ application and the highest kernels per ear (588) were obtained from the application of $92 \mathrm{~kg} \mathrm{~N} \mathrm{ha-1} \mathrm{although} \mathrm{there} \mathrm{was} \mathrm{no} \mathrm{significant} \mathrm{difference}$ between the application of 69 and $92 \mathrm{~kg} \mathrm{~N}$ ha-1. Regarding to ear length the data showed that the longest ear $(23.63 \mathrm{~cm})$ was obtained from the application of $92 \mathrm{~kg} \mathrm{~N} \mathrm{ha-1.} \mathrm{The} \mathrm{effect} \mathrm{of} N$ on grain yield indicated that there is no significant difference between the application of 69 and $92 \mathrm{~kg} \mathrm{~N} \mathrm{ha-1} \mathrm{even} \mathrm{if} \mathrm{there} \mathrm{is} \mathrm{a} \mathrm{slight} \mathrm{difference} \mathrm{on} \mathrm{yield.} \mathrm{Generally,} \mathrm{maximum} N$ fertilization level $(92 \mathrm{Kg} \mathrm{N} / \mathrm{ha})$ in this study area showed increase in growth and yield components (number of kernels per ear and ear length). However the application of $69 \mathrm{~kg} \mathrm{~N}$ ha-1 seems adequate to get the optimum yield.
\end{abstract}

Keywords:

Economic advantage, Productivity, Nitrogen Fertilizer.

Cite This Article: Mitiku Woldesenbet, and Asnakech Haileyesus, "EFFECT OF NITROGEN FERTILIZER ON GROWTH, YIELD AND YIELD COMPONENTS OF MAIZE (ZEA MAYS L.) IN DECHA DISTRICT, SOUTHWESTERN ETHIOPIA" International Journal of Research - Granthaalayah, Vol. 4, No. 2 (2016): 95-100. 


\section{INTRODUCTION}

Maize (Zea mays L.) is the world's widely grown highland cereal and primary staple food crop in many developing countries (Kandil, 2013). It was originated in America and first cultivated in the area of Mexico more than 7,000 years ago, and spread throughout North and South America (Hailare, 2000). In the world production, maize is ranked as the third major cereal crop after wheat and rice (Zamir et al., 2013). In 2014, the United States topped the list of ten maize producing countries which includes China, Brazil, EU-27, Ukraine, Argentina, India, Mexico, South Africa and Canada with an amount of about 351 million metric tons (Statista, 2015).

World production of white maize is currently estimated to be around 65 to 70 million tons. Among the individual geographical regions of the developing countries, white maize production has a paramount importance in Africa. The main white maize producers in Africa include Kenya, Tanzania, Zambia and Zimbabwe (Kidist, 2013).

Maize is an important crop in Ethiopia. It is grown in the mid highland areas of the country. There are huge tracts of land in all regions suitable for maize farming. Maize is mainly produced in SNNPR and Oromia regions where there are about 1.77 million hectares under cultivation. (Ethiopian Investment Agency (www.eia.gov.et)). Maize is grown on more than 2 million ha $(15 \%)$ of Ethiopia's from 14 million ha cultivated land. It is second to tef (Eragrostis tef) in area coverage but first in productivity and total production among all cereals. Approximately 9.3 million smallholder farmers in this country grow maize, mainly for human consumption. It is also an important source of income for these farmers.

Ethiopia is the fifth largest producer of maize in Africa and smallholder farmers make up $94 \%$ of the crop production. The country produces white maize, the preferred type of maize in neighboring markets. As the cheapest source of caloric intake in Ethiopia, providing $16.7 \%$ of per capita calorie intake nationally, maize is an important crop for overall food security. (Agricultural Growth Program (ethioagp.org))

In Kaffa zone Decha District the production status reaches over 2400 tons. It is cultivated in all kebeles and it covers 8000 ha among the cereal crops (Annual report, Decha District agricultural office, 2015).

Maize is used as directly human food in different forms. It is composed of approximately 76 $88 \%$ of carbohydrate, $6-16 \%$ of protein, $4-5.7 \%$ fat and $1.3 \%$ of minerals. So that it is more balanced nutritionally and agriculturally small quantity grains are currently used for livestock as well as poultry feed and this is expected to increase with the development of the livestock and poultry production enterprise in the country. However, the productivity is very low as compared to the average national productivity.

The low productivity of maize is attributed to many factors like decline of soil fertility, poor agronomic practices, and limited use of input, insufficient technology generation, poor seed quality, disease, insect, pest and weeds. Among the limiting nutrients, nitrogen fertilizer is the most limiting factors in the study area since the area is characterized with high amount of rainfall that causes leaching and runoff. Therefore, the objective of this study is: 
- To evaluate the effect of nitrogen fertilizer on maize growth, yield and yield components

\section{MATERIAL AND METHODS}

\subsection{DESCRIPTION OF EXPERIMENTAL SITE}

The study was conducted in Kaffa Zone, Decha District, Modyo Gombera kebele of Southern Nations, Nationalities and Peoples' Regional State. The site is located $475 \mathrm{~km}$ southwest of Addis Ababa. Geographically it is located in latitude of $07^{0} 22^{\prime} 34^{\prime \prime} \mathrm{N}$ and longitude of $02^{0} 29^{\prime}$ 89 "E. The altitude of the specific site is 1815 masl. The soil type is integration of clay and clay loam. The annual rainfall ranges from $1500 \mathrm{~mm}$ to $2000 \mathrm{~mm}$ and annual temperature range of $20^{0}$ to $24^{0} \mathrm{C}$.

\subsubsection{EXPERIMENTAL MATERIALS}

A high yielding maize variety, $\mathrm{BH}$ 661, which adapts to the agro-ecology of the area, was used. BH 661 is a drought resistant hybrid varieties released under DTMA (Drought Tolerant Maize for Africa) project in Ethiopia in 2011 (CIMMYT, 2014) at Bako Agricultural Research Center through the national maize research program (AGP, 2015). It has a wider adaptability (mid to transition highlands) (CIMMYT, 2014) and grows well at an altitude ranging from 1650 to 2200 meter above sea level with an annual precipitation of 1000 to $1500 \mathrm{~mm}$. It needs about 170 days for maturity and performs better under high rainfall, good soil condition and high dose of fertilizer application (NSIA, 1998).

Nitrogen fertilizer in the form of urea $(46 \% \mathrm{~N})$ was used by calculating amount of $\mathrm{N}$ from $100 \mathrm{~kg}$ of urea. The $\mathrm{N}$ fertilizer was applied at different rates to the experimental plots while the recommended rate of phosphorus fertilizer in the form of DAP (Di-ammonium Phosphate) was applied uniformly to all plots at the time of sowing.

\subsubsection{TREATMENT AND EXPERIMENTAL DESIGN}

The treatment consists of five rates of $\mathrm{N} 0,23 \mathrm{~kg} \mathrm{~N} \mathrm{ha}^{-1}, 46 \mathrm{~kg} \mathrm{~N}^{-1}, 69 \mathrm{~kg} \mathrm{~N}^{-1}$ and $92 \mathrm{~kg} \mathrm{~N}$ $\mathrm{ha}^{-1}$ and applied two times i.e. half at 41 days after sowing and the remaining half at late vegetative stage before tasseling.

The size of each plot was $1.8 \mathrm{~m} \mathrm{X} 2.4 \mathrm{~m}\left(4.32 \mathrm{~m}^{2}\right)$. The distance between plots was $50 \mathrm{~cm}$ and between blocks was $1 \mathrm{~m}$. The seeds were sown in rows of $75 \mathrm{~cm}$ at the spacing of $25 \mathrm{~cm}$ between seeds. The area of total experimental site was therefore $141 \mathrm{~m}^{2}$. The experiment was laid out in a randomized compete block design (RCBD) with 5 treatments replicated three times.

\subsection{EXPERIMENTAL PROCEDURES}

\subsubsection{FERTILIZER APPLICATION AND FIELD ACTIVITY}

All field activities were carried out with the following standards. The site was cleared and cultivated three times in 15 days difference. After the selected site was ploughed three times in 
15 days interval, cleaned and prepared, leveling, block and plot making activities have been followed.

Planting (sowing) was aimed to be done in $2^{\text {nd }}$ to $3^{\text {rd }}$ week of March 2015. But due to absence of rain it was extended to $4^{\text {th }}$ week and sown on $28^{\text {th }}$ March 2015 by placing the seeds in hand made furrows at the inter and intra row spacing of $75 \mathrm{~cm}$ and $25 \mathrm{~cm}$, respectively.

The recommended rate of $\mathrm{P}$ (DAP) fertilizer (100 kg/ha) was equally applied to all plots at the time of sowing. For the $\mathrm{N}$ fertilizer application urea was applied at the specified rates and timing. Weeds were managed by hand weeding after weed emergence and late emerging weeds were removed by hoeing to avoid interference with the maize plant for the $\mathrm{N}$ applied.

\subsection{DATA COLLECTION AND MEASUREMENT}

Data on plant growth parameters (plant height, leaf number), and yield and yield components (number of kernels per ear, number of rows per ear, ear length and total grain yield) were collected and analyzed.

\subsection{DATA ANALYSIS}

The data was subjected to analysis of variance (ANOVA) at 0.05 probability level of significance by scientific calculator.

\section{RESULTS AND DISCUSSION}

\subsection{EFFECTS OF NITROGEN FERTILIZER ON GROWTH PARAMETERS}

The result indicated that there is significant difference among treatments $(\mathrm{P}<0.05)$. It was observed that, there is an increase in number of leaves with an increase in $\mathrm{N}$ level. The data showed that the minimum number of leaves per plant (15.8) was obtained from no $\mathrm{N}$ application and the maximum numbers of leaves per plant (17.2) were obtained from the application of 69 and $92 \mathrm{~kg} \mathrm{~N}$ ha-1. This result is supported by Badr and Authman (2006) who reported that increasing nitrogen fertilizer rate from zero up to $250 \mathrm{~kg} N /$ ha significantly increased the number of leaves/plant of maize.

Table 1: The effect of $\mathrm{N}$ fertilizer on number of leaves per plant, plant height and ear length

\begin{tabular}{llll}
\hline $\mathrm{N}$ rate $\left(\mathrm{kg} \mathrm{ha}^{-1}\right)$ & $\begin{array}{l}\text { Number of } \\
\text { leaves per plant }\end{array}$ & Plant height $(\mathrm{cm})$ & Ear length $(\mathrm{cm})$ \\
\hline 0 & 15.8 & 347.33 & 22.63 \\
23 & 16.3 & 351.73 & 22.8 \\
46 & 17 & 353.00 & 23.16
\end{tabular}




\begin{tabular}{llll}
69 & 17.4 & 360.40 & 23.43 \\
92 & 17.4 & 360.66 & 23.63 \\
\hline LSD $(\%)$ & 0.23 & 307.9 & 0.14 \\
\hline CV $(\%)$ & 2.5 & 5.0 & 2.7 \\
\hline
\end{tabular}

The result also shows that there is an increase in plant height with an increase in nitrogen level. The tallest plant $(360.66 \mathrm{~cm})$ was recorded from the application of $92 \mathrm{~kg} \mathrm{~N}^{-1}$ and the shortest $(347.33 \mathrm{~cm})$ from no N application (Table2). Similarly, Kandil (2013) reported that plant height of maize increased with increased level of nitrogen from 214 to $429 \mathrm{~kg} \mathrm{~N} / \mathrm{ha}$.

\subsection{EFFECT OF NITROGEN FERTILIZER ON MAIZE YIELD COMPONENTS AND GRAIN YIELD}

With regard to the effect of nitrogen levels on ear length, the results showed that there is slight increase on ear length with an increase on $\mathrm{N}$ level from 0 to $92 \mathrm{~kg} \mathrm{ha}^{-1}$. The study of Kandil (2013) indicated that ear length of the maize increased when $\mathrm{N}$ level increased from 214 to 429 $\mathrm{kg} \mathrm{N} \mathrm{ha}^{-1}$ resulting to $17.77 \mathrm{~cm}$ and 20.15 , respectively.

Also the number of kernels per ear, was significant $(\mathrm{P}<0.05)$ affected. The results revealed that maximum number of kernels was produced when $92 \mathrm{~kg} \mathrm{~N}$ ha-1 was applied as compared to other levels (Table 2).

Table 2: The effect of $\mathrm{N}$ fertilizer on number of kernel per plant, number of rows per ear and grain yield

\begin{tabular}{llll}
\hline $\mathrm{N}$ rate $\left(\mathrm{kg} \mathrm{ha}^{-1}\right)$ & $\begin{array}{l}\text { Number of } \\
\text { kernel per plant }\end{array}$ & $\begin{array}{l}\text { Number of } \\
\text { rows per ear }\end{array}$ & $\begin{array}{l}\text { Grain } \\
\left(\mathrm{kg} \mathrm{ha}^{-1}\right)\end{array}$ \\
\hline 0 & 497.86 & 12.8 & 72.2 \\
23 & 524.66 & 13.06 & 72.1 \\
46 & 574.13 & 13.33 & 73.15 \\
69 & 587.20 & 13.33 & 75.5 \\
92 & 588.00 & 13.33 & 73.3 \\
\hline $\mathrm{CV}(\%)$ & 5.8 & 0.4 & 2.04 \\
\hline LSD $(\%)$ & 1123 & 0.04 & 2.42 \\
\hline
\end{tabular}

The result shows that the application of different levels of nitrogen $\left(46 \mathrm{~kg} \mathrm{ha}^{-1}, 69 \mathrm{~kg} \mathrm{ha}^{-1}\right.$ and 92 $\mathrm{kg} \mathrm{ha}^{-1}$ ) is non-significant on number of rows per plant. This result is similar to Arif et al. (2010) who found non-significant result by applying $80 \mathrm{~kg} \mathrm{~N} \mathrm{ha}^{-1}, 120 \mathrm{~kg} \mathrm{~N}^{-1}$ and $160 \mathrm{~kg} \mathrm{~N} \mathrm{ha}^{-1}$. Moraditochaee et al. (2012) also showed that the application of $\mathrm{N}$ fertilizer was non-significant on number of rows per ear. 
It was also observed that when the nitrogen level increase to the highest level $\left(92 \mathrm{~kg} \mathrm{ha}^{-1}\right)$, the yield start decreasing (Table 2). This indicates that the application of $69 \mathrm{~kg} \mathrm{~N}^{-1}$ seems the optimum rate to get the maximum yield per unit area.

\section{CONCLUSION}

Depending on the results found the recommendations to the study area and similar agro ecological areas are optimum amount of $\mathrm{N}$ fertilizer, in this case $69 \mathrm{~kg} \mathrm{~N} \mathrm{ha}^{-1}$, should be used with split application, half at early stage (41-45 days) and the remaining half at early tasselling stage, to earn more yields. Further studies should be done to identify the chemical composition of the soil of the study area that may have positive or negative impact on the level of fertilization of the area.

\section{REFERENCES}

[1] Annual report, Decha District Agricultural Office, 2015. Progressive status report on maize production.

[2] Arif, M. I. Amin, M.T. Jan, I. Munir, K. Nawab, N.U. Khan, and K.B. Marwat, 2010. Effect of Plant Population, Nitrogen Levels and Methods of Application on Ear Characters and Yield of Maize.

[3] Badr, M.M. and Authman, 2006. Effect of plant density, organic manure, biological and mineral nitrogen fertilizers on maize growth, yield and soil fertility. Annual Agricultural Science, 44(1): 75-88.

[4] Kandil, E.E., 2013. Response of Some Maize Hybrids (Zea mays L.) to Different Levels of Nitrogenous Fertilization. Journal of Applied Sciences Research, 9(3): 1902-1908.

[5] Kidist, 2013. Growth and productivity of maize as influenced by rate and time of nitrogen. Journal of Applied Sciences Research, 9(4): 1920-1928.

[6] Hailare,L., 2000. Corn: An American Native. Spanning the Gap The newsletter of Delaware Water Gap National Recreation Area Vol. 22 No. 1 Spring 2000. U.S. Dept. of the Interior National Park Service

[7] Moraditochaee, M., M. K. Motamed, E. Azarpour, R. K. Danesh and H. R. Bozorgi, 2012. Effects of Nitrogen Fertilizer and Plant Density Management in Corn Farming. ARPN Journal of Agricultural and Biological Science, 7(2): 144-152.

[8] Mangeisdorf, P.C., Mac Neish, R.S., Galinat, W.E., 1964. Domestication of corn science. 143

[9] NAFIS, 1998. National Farmers Information Service. (www.nafis.go.ke).

[10] CIMMYT (International Maize and Wheat Improvement Center), 2014. http://dtma.cmmyt.org

[11] Zamir M.S.I., Yasin G., Javeed H.M.R., Ahmad A.U.H., Tanveer A., Yaseen M., 2013 Effect of different sowing techniques and mulches on the growth and yield behavior of spring planted maize (Zea mays L.). Cercetări Agronomice în Moldova, 1(153): 77-82. 